\title{
PLANT EXTRACTS USED FOR THE CONTROL OF ENDO AND ECTOPARASITES OF LIVESTOCK: A REVIEW OF THE LAST 13 YEARS OF SCIENCE
}

(Extratos de plantas usados no controle de endo e ectoparasitos de animais de produção: uma revisão dos últimos 13 anos de ciência)

\section{Marcelo Beltrão Molento ${ }^{1 * h t t p: / / o r c i d . o r g / 0000-0003-0572-5628, ~ A m a n d a ~ C h a a b a n ², ~ E r i k ~ N u n e s ~ G o m e s ³, ~ V e r a ~ M a r i a ~}$ Carvalho da Silva Santos², Juliana Bello Baron Maurer ${ }^{1}$}

${ }^{1}$ Federal University of Parana, Curitiba - PR, Brazil; ${ }^{2}$ Catarinense Federal Institute, Araquari, Santa Catarina, Brazil; ${ }^{3}$ The State University of New Jersey, New Brunswick, New Jersey, United States of America.

*Corresponding author: molento@ufpr.br

ABSTRACT - A variety of endo and ectoparasites can affect livestock, causing poor animal performance and low welfare conditions. Haemonchus contortus (Trichostrongyloidae), Rhipicephalus microplus (Ixodidae), Cochliomyia sp. and Lucilia sp. (Calliphoridae) are some of the most important parasites to livestock in Brazil and in many other tropical and subtropical countries, where farmers need to be vigilant. Although a constant parasite control uses large-spectrum anthelmintics or synthetic insecticides, giving a timely potent reduction of the infections, they also represent a threat to the lifespan of these compounds due to drug-selected parasites. Thus, the development of plant-based therapies is a solid alternative for standard, agroecological, and holistic farming systems, as well as it is an important ally to combat drug resistant parasite populations. In this article, we discussed the scientific literature on plant extracts, notably hydroalcoholic extract or essential oils, used for the control of the above livestock parasites published in the last 13 years. Our objective was to pinpoint the most important issues for this promising area of research, exploring the potential and the challenges that are facing us by examining more than 150 in vitro and in vivo studies. Almost all the authors reported positive data from plants or isolates, the most important challenges that were faced during our search were the lack of a proper experimental study design, and the deficiency in the characterization of the plants used. It is our opinion that plant-based products may be a solid choice for parasite control in livestock animals achieving high welfare standards and mitigate farming input (i.e. use of chemicals and their waste into the environment).

Key words: multidrug resistance; organic farming; parasite infections; phytotherapy; ruminants. 
Plant extracts used for the control of endo and ectoparasites of livestock: a review of the last 13 years of science

RESUMO - Uma variedade de endo e ectoparasitos pode infectar animais de fazenda causando baixa produtividade e baixa condição de bem-estar. Haemonchus contortus (Trichostrongyloidae), Riphicephalus microplus (Ixodidae), Cochliomyia sp. e Lucilia sp. (Calliphoridae) são os parasitos mais importantes para ruminantes no Brasil e em muitos países tropicais e subtropicais, onde produtores devem ficar atentos. Muito embora o controle convencional de parasitos seja constante, usando anti-helmínticos de largoespectro ou inseticidas sintéticos, permitindo uma eficácia aceitável, isso também representa um risco para a vida útil destes produtos, devido a seleção de parasitos contra as drogas. Assim, o desenvolvimento de medicamentos com extratos de plantas podem ser uma alternativa consistente em sistemas pecuários tradicionais, agroecológicos e holísticos, assim como ser um importante aliado para combater populações de parasitos resistentes. Neste artigo, nós discutimos as pesquisas com o uso de extratos de plantas, notadamente, extratos hidroalcoólicos ou óleos essenciais, usados no controle dos parasitos listados acima, nos últimos 13 anos. Nosso objetivo foi identificar os pontos mais importantes nesta promissora área de pesquisa, buscando os potenciais e os desafios que estão em nossa frente, examinando mais de 150 estudos in vitro and in vivo. Quase a totalidade dos autores relatou dados positivos com o uso de plantas ou isolados, as maiores dificuldades encontradas durante a pesquisa foi a falta de um desenho experimental correto e caracterização das plantas usadas. É nossa opinião que produtos derivados de plantas podem ser uma alternativa sólida para o controle de parasitos em animais de fazenda, atingindo alto grau de bem-estar animal, mitigando o input negativo das fazendas (ex. uso de químicos e seus desejos no meio ambiente).

Palavras-chave - Fitoterapia; infecções parasitárias; pecuária orgânica; resistência múltipla as drogas; ruminantes.

\section{INTRODUCTION}

Livestock production is an important activity worldwide that requires knowledge and the application of modern technologies to be effective and profitable. Welfare conditions of farm animals integrates the health status of livestock and depends on many management strategies that focus in alleviating the imposed stress conditions, i.e. high animal density, contact with infection agents (virus, bacteria, parasites), unbalanced nutrition, and short gestational intervals. In developing countries, particularly those located in tropical and subtropical regions, gastrointestinal nematode infections, acute and chronic), can significantly delay production, decrease revenues and, in extreme cases, 
be the major cause of death in young animals. In addition, the infestation of living tissues by blowfly larvae and the cattle tick are considered additional problems that affect livestock animals, significantly reducing their performance (Graf et al., 2004; Grisi et al., 2014).

Conventional parasite control against helminths, ticks, flies and myiasis caused by fly larvae depends almost exclusively on the regular usage of broad-spectrum anthelmintics or synthetic insecticide products. The timely potent reduction of the infections by using such drugs represent a major milestone to the livestock industry and are an important factor when setting up any animal health program (Graf et al., 2004). However, the suppressive use of these compounds has caused a threat to the lifespan of these compounds due to the selection of resistant parasite populations (Fortes and Molento, 2013). The use of synthetic antiparasitic drugs also represents a risk to food safety with an unprecedented environmental impact (Ballweber and Baeten, 2012; Beynon, 2012).

Medicinal plants have been used as therapeutic agents in traditional and popular medicine (Khater, 2012; Pavela and Benelli, 2016), and the use of bioactive compounds derived from plants have been investigated as parasiticides in an attempt to be effective against resistant populations, for their relatively low-environmental impact, and for their local availability, improving animal health of distant communities. In South America, a continent with the largest biodiversity on earth, communities hold a valuable traditional knowledge relating the use of medicinal plants (Di Stasi et al., 2002). This vast natural diversity illustrates the potential of the region to have several bioactive products that may be used for the treatment of diseases of humans and animals.

Phytotherapy is being used in large scale parasite control programs in humans (i.e. artemisinin treatment of malaria in Africa and Asia), and may also be a tangible option to fight the alarming drug resistant situation in livestock worldwide. In recent years, efforts have been made towards the application of medicinal plants and their extracts as an alternative or complementary treatment to endo and ectoparasite infections (Khater, 2012; Athanasiadou et al., 2007; Regnault-Roger et al., 2012; Soldera-Silva et al., 2018). However, scientific effectiveness of most plants used as antiparasitic products in laboratory conditions have yet to be confirmed in the field (Molento et al., 2011). Another major issue when applying plant-based extracts as pest control agents is the lack of standardization, which is still considered a limitation to large-scale use (Atanasov et al., 2015). Thus, the investigation and validation of biological properties of plant-derived substances, as well as their chemical characterization, are critical for the scientific 
endorsement of veterinary phytotherapy field. New technologies are also being developed that will help to unravel the mechanism of action of most of the main isolated compounds and that nanopharmacology should play an important role in the next generation of enterprise (Cruz and Molento, 2015). Lots of obstacles still have to be surpassed to meet the industry demand and all the governmental regulatory steps.

The aim of the present review was to provide up-to-date information on the scientific data from in vivo and in vitro studies and discuss the biological activity of plantderived substances against livestock parasites from 2007 to 2019. We looked for the most important issues to this promising area of research, considering their potential and challenges by examining more than 150 articles available at Google Scholar, NCBI/PUBMED, Scielo, Science Direct, Scopus and Web of Science. We used the key words: -parasite scientific name-, plant-base therapy, phytotherapy, livestock, cattle, ruminants, and examined only full articles. More detail information should be looked at the following Tables.

\section{DEVELOPMENT}

\section{General characteristics and uses of plant extracts}

Phytotherapy products correspond to all preparation, aqueous or hydroalcoholic extracts, syrups and essential oils (EOs), using parts of plants (leaves, stems, roots, flowers, fruits and/or seeds), that may exhibit therapeutic properties. These activities are related to the presence of bioactive compounds, which have distinct chemical characteristics, classified into primary or secondary metabolites (Briskin, 2000). Secondary metabolites, also called special metabolites, are compounds that are biosynthetically derived from the plant's primary metabolism and contain complex structures. These products have also low molecular mass and distinct biological activities (Balandrin et al., 1985).

Although secondary metabolites do not present essential functions in the plants' life cycle, these molecules play an important role to their adaptation to the environment, generating advantages in competition and perpetuation of some species. For example, they may be involved in the pollination process or in the biological defense, acting as chemical defenders against microorganisms, insects, larger predators or even other plants (Balandrin et al., 1985). Most of secondary metabolites can be classified into three chemically distinct groups: terpenoids, synthesized mainly from mevalonic acid or 
methylerythritol 4-phosphate; phenolic compounds, derived from shikimic or malonic acid; and nitrogen compounds, which are derived from aromatic and aliphatic amino acids (Verma and Shukla, 2015). The products with antiparasitic properties are usually associated with the presence of secondary metabolites, such as EOs, tannins or polyphenols (Khater, 2012; Hoste and Torres-Acosta, 2011).

EOs are a mixture of volatile organic compounds produced by aromatic plants and are found in different organs (i.e., flowers, leaves, stems, seeds, fruits, roots, or bark). These oils are mainly secreted and storedin idioblasts, canals, epidermis cells or glandular trichromes (Bakkali et al., 2008). The extraction EOs can be done by hydrodistillation, steam distillation, dry distillation or others. EOs are liquid, volatile, limpid or rarely colored, lipid soluble and soluble in organic solvents, generally with lower density than water (Stratakos and Koidis, 2016). EO constituents are mainly terpenoids and, to a lesser extent, phenylpropanoids. The plant secondary metabolism is genetically regulated but also strongly influenced by the plant's interaction with biotic and abiotic environmental factors (Verma and Shukla, 2015). Thus, the chemical profile and productivity of EOs and other secondary metabolites can vary according to the type of extraction, climate (i.e. precipitation, temperature, sun exposure), soil composition, plant organ, age and vegetative cycle, circadian rhythm and plant-herbivore interactions, among other factors (Vallad and Goodman, 2004; Pavela and Benelli 2016).

EOs have been widely used against bacteria, virus, fungus, parasites, insects, and in cosmetic applications, especially by pharmaceutical, agricultural and food industries. These compounds exert their activities on insects through neurotoxic effects involving gamma-amino butyric acid (GABA), octopamine synapses and inhibiting acetylcholinesterase (Khater, 2012; Regnault-Roger et al., 2012). EOs are natural in origin and biodegradable, and frequently effective in relatively small quantities. Usually, EOs have an average of 10 to 200 constituents, believed to act in additive and synergy effect. This phyto-complex may also be used to delay insect resistance. EOs often present low toxicity to mammalian cells and are relatively well studied experimentally and clinically. EOs represent a sustainable source of disease control, reducing economic losses, treatment costs and have the possibility to affect resistant parasite populations (Khater, 2012; Regnault-Roger et al., 2012).

\section{Efficacy of plants for the control of Haemonchus contortus}

Endoparasite infections, especially caused by $H$. contortus, are one of the most important sanitary and economic problems of livestock. Common symptoms include 
apathy, weight loss, anemia, diarrhea, and even death of young animals. To control these infections, farmers usually use conventional anthelmintic products in preventive programs (Fortes and Molento, 2013). Several alternatives have been suggested to overcome this problem and the use of herbal medicines is in an advanced stage of research, showing promising data (Seddiek et al., 2011; Adenubi et al., 2016; Pavela and Benelli, 2016).

The articles listed in Table 1 suggest that plant extracts that are rich in condensed tannins, flavonoids, or saponins have potent activity against $H$. contortus. On the other hand, several other papers focus on the use of EOs, mainly rich in thymol, carvacrol, geraniol, pulegone and/or eugenol.

Condensed tannins are natural antioxidants used against nematodes and act by reducing the excretion of eggs by decreasing the fertility of female parasites. Lambs infected with endoparasites consuming plants with high tannin contents had a reduction of parasite load (Lisonbee et al., 2009). Flavonoids, on the other hand, can have an indirect effect, since their antioxidant activities can also potentially increase the animals' immune response (Lakshmi et al., 2010). As for the saponins, these compounds are known to interact with collagen proteins from the nematode cuticles, and this interaction is believed to be responsible for their nematotoxic effects (Argentieri et al., 2008).

\section{Efficacy of plants for the control of Rhipicephalus microplus}

Ticks are the main parasite problem of cattle in most tropical countries, where the infestation by $R$. microplus cause enormous economic impact (Jonsson and Piper, 2007; Molento et al., 2013; Benelli et al., 2016). Due to the lack of up-to-date technical assistance and long-term epidemiological studies, tick control is usually done with the indiscriminate use of commercial synthetic products for both dairy and beef cattle. New technologies are currently being developed for tick control and, among them, microbiological control, breed selection, target selective treatment and the use of plant extracts show the most promising results (Molento et al., 2013; Mapholi et al., 2014; Webster et al., 2015; Adenubi et al., 2016; Pavela and Benelli, 2016). A literature overview on plant-derived products used against $R$. microplus in different in vitro tests are showed in Table 2.

Some phenolic compounds found in the phytochemical analyses have significant acaricide effect, however, the mechanism of action of these compounds is still to be established (Krimer-Malesevic et al., 2011). Terpenoids are involved in the defense 
mechanism of some plants against mites. Terpene-rich methanol extracts of Hypericum polyanthemun (millerpertius) at concentrations of 50, 25, 12.5 and $6.25 \mathrm{mg}^{-\mathrm{ml}^{-1}}$, obtained, respectively, 100,96.7, 84.7 and $52.7 \%$ mortality of $R$. microplus, $48 \mathrm{~h}$ using the larval immersion test (Ribeiro et al., 2007). Hexanic extract of Piper aduncum (spiked pepper) presented a LC50 of $9.30 \mathrm{mg} \cdot \mathrm{ml}^{-1}$ for larvae and the reduction of tick reproduction (adult immersion test) ranged from 12.48 to $54.22 \%$ (Silva et al., 2009). Ribeiro et al. (2010) assessed the acaricidal properties of the EO from Hesperozygis ringens on the newly hatched larvae of the cattle-tick using the immersion tests, showing a $L_{50}$ of $0.260 \mu \mathrm{l} / \mathrm{ml}$. A similar evaluation using the package immersion tests was assessed by Lima et al. (2014), with hexanic extract of Piper tuberculatum fruits, where the authors found a $L_{50}$ of $0.04 \mathrm{mg} / \mathrm{ml}$. The acaricidal efficacy of Lippia gracilis EO was assessed against organophosphate-resistant and susceptible strains of $R$. microplus by Costa-Junior et al. (2016), using two genotypes of L. gracilis (106 and 201), thymol and carvacrol chemotype, respectively. The thymol chemotype was more effective than the carvacrol, showing a $\mathrm{LC}_{50}$ of $1.02 \mathrm{mg} / \mathrm{ml}$ (Table 1). The EO extracted from L. triplinervis shoots was also investigated for acaricidal activity on $R$. microp/us (Lage et al., 2012). The authors reported an efficacy of $95.7 \%$ using $2.5 \mathrm{mg} / \mathrm{ml}$ of EO on newly hatched larvae (larval packet test) (Lage et al., 2012). Likewise, the methanol extract of Acmella oleracea showed better results on $R$. microplus, with $98.1 \%$ of mortality, using $1.6 \mathrm{mg} / \mathrm{ml}$. More recently, a rare chemotype of Cinnamomum verum was studied by Monteiro et al. (2017), demonstrating a LC 50 of 1.00 $\mathrm{mg} / \mathrm{ml}$.

\section{Efficacy of plants for the control of Blowflies}

Several flies from Calliphoridae and Cuterebridae families have received considerable attention due to human and animal infestation inducing primary, secondary or facultative myiasis (Papavero and Couri, 2012). Infestation of living tissues mainly by Cochliomyia hominivorax causes a loss of US\$336 million/year in Brazil (Grisi et al., 2014).

Nowadays, conventional control of myiasis depends almost exclusively on synthetic insecticides, representing a major risk to food safety, especially with high residues in meat and milk (Moya-Borja, 2003; Chaaban et al., 2017a). Since 1940, the synthesis of long-acting insecticides has led experts to hope for the control of various diseases caused or transmitted by arthropods or even to eradicate unwanted species. However, the toxicity of synthetic insecticides and the negative effects on human health and the environment, coupled with the development of insecticide resistance, led to a recovery of the interest in low-impact botanical insecticides (Pavela, 2015). The great 
biodiversity in South America has stimulated the increasing interest on the chemical composition and the biological activity of some native plants. The use of plant extracts in the control of veterinary ectoparasites has increased considerably, owing their popularity mainly with organic farmers and environmentally conscious consumers (Regnault-Roger et al., 2012; Ellse and Wall, 2014). Thus, plant extracts appear as a promising alternative for controlling myiasis (Khater et al., 2011; Callander and James, 2012; Khater, 2014; Shalaby et al., 2015). Table 3 presents the main research using plant extracts against myiasis caused by the larvae of some economically important flies.

Studies with L3 of C. macellaria and L. cuprina showed that sub-lethal doses of EO interfered with the insects physiological parameters (Chaaban et al., 2017 b, 2019 a,b). Reports on retarded larval growth and changes of physiological parameters at sub-lethal concentrations were also described after treatment of $L$. sericata with fenugreek, celery, radish, and mustard oils (Khater and Khater, 2009). Changes in larvae cuticle necrosis, abnormalities, decrease in motility and adult deformity were also observed using plant extracts (Shalaby et al., 2016; Chaaban et al., 2017a, 2017b).

The wide range of results observed on toxicity studies may be related to the insect life cycle stages, the mechanism of action (i.e. contact and/or ingestion) and the different sensitivity between Diptera species (Callander and James, 2012). The influence of EOs of lettuce (Lactuca sativa), chamomile (Matricaria chamomilla), anise (Pimpinella anisum), and rosemary (Rosmarinus officinalis), solubilized in surfactant and distilled water on postembryonic development of $L$. sericata were evaluated, showing $L D_{50} S$ of $0.57,0.85,2.74$ and $6.77 \%$, respectively (Khater et al., 2011). The assessment of toxicity in immersion tests with Tween 20 containing 50\% EO of Melaleuca alternifolia (tea tree), using L3 of L. cuprina determined a toxicity rate lower than $50 \%$, demonstrating a greater susceptibility of the $1^{\text {st }}$ and $2^{\text {nd }}$ instar larvae (Callander and James, 2012). The bioefficacy of methanolic extracts of Azadirachta indica leaves on the survival and development of myiasis-causing larvae of Chrysomya bezziana was assessed by Singh and Kaur (2016). The authors reported a significant toxic effect by the extract, indicating that $A$. indica may be used in controlling the larvae of $C$. bezziana.

The biocontrol of Blowflies by parasitic wasps, nematodes, bacteria, fungi and viruses has been proposed and offers a particularly interesting approach to ectoparasites management (Wall, 2012; Sandeman et al., 2014). However, herbal medicines are in an advanced stage of research, showing promising results, which will be listed below. In vivo tests are essential to recommend the exact doses to be applied on animals, however we 
need large scale studies to determine the real effective concentrations, even including populations that are geographically distant. Despite the increase on studies of plant extracts for myiasis control, some gaps remain to be filled. In Table 3, we note that $52.63 \%$ of the papers did not describe which part of the plant were used. Similarly, $89.47 \%$ of them did not show the chemical composition of the evaluated plant. Therefore, our opinion is that these data are incomplete, representing an important limitation regarding high-quality scientific information to base alternative forms of treatments for ecto and also to endoparasites of livestock. These limitations are particularly important for all reports and we still have to address this issue to be able to better contribute to the phytotherapy field of science.

\section{Use of individual compounds from plant extracts against parasites of livestock}

Determining the in vivo or in vitro activity of the isolated compounds from plants can bring great advances to parasite control, since it allows their use in specific formulations with maximized efficiency. Such data can be used for the exploration of additive and synergic effects and the exclusion of potential antagonistic compounds present in different plant extracts. In this sense, the evaluation of isolated compounds as parasiticides has been increasing considerably in the last decade (Table 4). The acaricidal activity of b-amino alcohol derivatives of limonene (1-methyl-4-(1-methylethenyl)-2-(4furfurylamine) cyclohexanol), against $R$. microplus was assessed by Ferrarini et al. (2008). The authors reported $100 \%$ larvae mortality at a concentration of $1.25 \mathrm{mg} / \mathrm{ml}$. The toxicity of thymol and carvacrol has also been studied. Thymol has showed a better acaricidal (against $R$. microp/us) activity when compared to carvacrol in the larval packet test and larval immersion test (Costa-Junior et al., 2016; Araújo et al., 2016). Likewise, the $L_{50}$ of $4.46 \mathrm{mg} / \mathrm{ml}$ and $\mathrm{LC}_{50}$ of $5.50 \mathrm{mg} / \mathrm{ml}$ were obtained for carvacrol and thymol, respectively using the adult immersion test. The effects from the interactions of these substances was suggested as a synergic effect in the control of $R$. microplus (Araújo et al., 2016). The acaricidal activity of spilanthol, one of the major chemical constituents of the flowers and leaves of Acmella oleracea, was assessed by Cruz et al. (2016). The data revealed a larval mortality of $91.3 \%$ from $0.8 \mathrm{mg} / \mathrm{ml}$ of this compound (Cruz et al., 2016).

Recent studies showed significant activities of thymol, bromelain, cinnamaldehyde and chlorogenic acid against different life stages of $H$. contortus (Table 4). The inhibitory effect of thymol was assessed on egg hatching by Camurça-Vasconcelos et al. (2007), where the authors found $93.6 \%$ of inhibition using $0.62 \mathrm{mg} / \mathrm{ml}$ of the isolate. Similarly, the toxicity of cinnamaldehyde was evaluated with the egg hatch test with a $L_{50}$ of 0.018 
Plant extracts used for the control of endo and ectoparasites of livestock: a review of the last 13 years of

$\mathrm{mg} / \mathrm{ml}$ on $H$. contortus (Katiki et al., 2017), while another study found that $500 \mu \mathrm{g} / \mathrm{ml}$ of chlorogenic acid was enough to cause 100\% egg hatch inhibition (Jasso-Díaz et al., 2017). Studies on larval development using individual compounds also presented promising data. Bromelain and the aqueous extract of Ananas comosus were studied in vitro against $H$. contortus, using the egg hatch test and the larval development test at concentrations of 0.15 and $0.25 \mathrm{mg} / \mathrm{ml}$, exhibiting 99.2 and 100\% efficacy, respectively (Domingues et al. 2013). The authors reported that the same substances showed reduced ( 89 and $42 \%$, respectively), efficacies when running an in vivo study.

\section{Challenges and opportunities to the science of phytotherapy}

Phytotherapy, as well as herbal medicine/herbalism, and ethnoveterinary, is a regular form of medical science and must be treated so, using all the available technology for its development and distinguished growth. The traditional use of herbs/plants has given rise to a modern discipline, which must comply to scientific standards, not relying in empirical appreciation and old knowledge (Ameh et al., 2010). The World Health Organization - WHO, has given support to the broad use and regulation of herbal medicine, even to the support of clinical trials and the evaluation of their residues (WHO, 2000, 2005, 2007).

Pharmacological activity of plant-derived isolates (effect, persistency, quality, safety/toxic signs, biosynthesis, drug-drug interaction and combination), must be a priority for novel data determinations, as we want to suggest their use in substitution to commercial products. The combination of herbal medicines and commercial products is another great option to fight drug resistant parasites, due to the increase mode of action of the distinctive resulting compound. Some of the studies that were reported in this article shed light into this new research area, determining the composition of plant extracts, and evaluating the toxicity of their individual constituents against livestock parasites (Chaaban et al., 2019). The critical synergic effect between compounds, within and between chemical classes, is another challenge, as the summing effect is dependent of many distinct and fundamental stimuli (i.e. plant phenotypic response, chemical interactions, etc.) (Santos et al., 2018).

An extra perspective is the false impression, from common users, that plant derive products are safer to the environment. Related to this, the risk of host toxic effect is also a major factor to be taken into account, as the skin can be damaged after an overdose of an isolate. Thus, apart from being a real possibility of substitution, some questions have 
arrived from plant-based products: (1) What are the real concerns if the world decides to go green? (2) What would be the impact of such products? and (3) How can we prepare the consumers to the use of these products judiciously? These questions still need large scale-studies to be elucidated.

On the other hand, there are significant advantages and solid global market opportunities for new ecofriendly products, as holistic farming can mitigate waste products, negative farm inputs and industrial by-products.

\section{CONCLUSIONS}

The above listed plant-derived products have demonstrated valuable activity against adult and larvae of $B$. microplus, nematode eggs and larvae and mature larvae of L. cuprina and $C$. macellaria at very low concentrations, showing no toxic signs using the A. salina model (Sprenger et al., 2015). We believe that plant-based products can be excellent candidates for the development of antiparasitic compounds against livestock parasites.

Nowadays, the demand for safe food-products and healthy animals, have created an opportunity to develop programs for resilient farms, opening a wide opportunity for agroecological commodities. The need to search for natural-product based strategies is also important to confront the problem of drug resistance, creating effective alternatives, which can be used in combination with other management strategies. These products shall be used in associations or rotation programs, reducing the parasite selection pressure and extending the lifespan of all products.

As pointed out in this review, several challenges still must be overcome in order to consolidate the use of plant extracts or isolated components for livestock parasite control. The main limitations are: the standardization of biological tests with plant extracts, toxicity assessment of individual compounds, identification of the mechanisms of action, improvement of product solubility and bioavailability, increase of pharmacological activity, tissue distribution and penetration, protection against physical and chemical degradation, solution stability and the increase of the product shelf-life, drug-drug interaction, overall cost and animal safety.

Furthermore, we think that nanotechnology has emerged as another promising area for the development of products in a wide range of applications (i.e. nanoparticles) (Gunasekaran et al., 2014; Cruz and Molento, 2015; Govindarajan et al., 2016a; Govindarajan et al., 2016b), that could well represent the solution to some of the complex issues raise in this review. Researchers have to face these central problems and provide 
reliable information to contribute to a safer environment, focusing in improving animal welfare and, at the end of the day, to our own existence.

\section{Acknowledgements}

The authors acknowledge the funding received from the Brazilian Federal Agency for Support and Evaluation of Graduate Education (CAPES) proc. n 88881.129327/201601 to the third author.

\section{REFERENCES}

ABDEL-SHAFY, S.; EL-KHATEEB, R.M.; SOLIMAN, M.M. et al. The efficacy of some wild medicinal plant extracts on the survival and development of third instar larvae of Chrysomyia albiceps (Wied) (Diptera: Calliphoridae). Tropical Animal Health and Production, v.41, n.8, p.1741-1753, 2009.

ACHARYA, J.; HILDRETH, M.B.; REESE R.N. In vitro screening of forty medicinal plant extracts from the United States Northern Great Plains for anthelmintic activity against Haemonchus contortus. Veterinary Parasitology, v.201, n.1, p.75-81, 2014.

ADEMOLA, I.O.; ELOFF, J.N. In vitro anthelmintic activity of Combretum molle (R. Br. ex G. Don) (Combretaceae) against Haemonchus contortus ova and larvae. Veterinary Parasitology, v.169 n.1, p.198-203, 2010.

ADENUBI, O.; FASINA, F.O., MCGAW, L.J.; et al. Plant extracts to control ticks of veterinary and medical importance: a review. South African Journal of Botany, v. 105, p. 178-193, 2016.

AKKARI, H.; EZZINE, O.; DHAHRI, S. et al. Chemical composition, insecticidal and in vitro anthelmintic activities of Ruta chalepensis (Rutaceae) essential oil. Industrial Crops and Products, v.74, p.745-751, 2015.

ALONSO-DÍAZ, M.A.; TORRES-ACOSTA, J.F.J.; SANDOVAL-CASTRO, C.A. et al. Comparing the sensitivity of two in vitro assays to evaluate the anthelmintic activity of tropical tannin rich plant extracts against Haemonchus contortus. Veterinary Parasitology, v.181, n.2, p.360-364, 2011.

AMEH， S.J.; OBODOZIE, O.O.; INYANG, U.S.; ABUBAKAR; M.S.; GARBA, M. Current phytotherapy - A perspective on the science and regulation of herbal medicine. Journal of Medicinal Plants Research, v.4, p.72-81, 2010. 
APEL, M.A.; RIBEIRO, V.L.S.; BORDIGNON, S.A. et al. Chemical composition and toxicity of the essential oils from Cunila species (Lamiaceae) on the cattle tick Rhipicephalus (Boophilus) microplus. Parasitology Research, v. 105, n.3, p.863-868, 2009.

ARAÚJO, L.X.; NOVATO, T.P.L.; ZERINGOTA, V. et al. Synergism of thymol, carvacrol and eugenol in larvae of the cattle tick, Rhipicephalus microplus, and brown dog tick, Rhipicephalus sanguineus. Medical and Veterinary Entomology, v.30, n.4, p.377-382, 2016.

ARGENTIERI, M.P.; D'Addabbo, T., Tava, A.; et al. Evaluation of nematicidal properties of saponins from Medicago spp. European Journal of Plant Pathology, v. 120, n. 2, p. 189197, 2008.

ATANASOV, A.G.; WALTENBERGER, B., PFERSCHY-WENZIG, E.M.; et al. Discovery and resupply of pharmacologically active plant-derived natural products: $A$ review. Biotechnology advances, v. 33, n. 8, p. 1582-1614, 2015.

ATHANASIADOU, S.; GITHIORI, J.; KYRIAZAKIS, I. Medicinal plants for helminth parasite control: facts and fiction. Animal, v. 1, n. 9, p. 1392-1400, 2007.

BACHAYA, H.A.; IQBAL, Z.; KHAN, M.N. et al. Anthelmintic activity of Ziziphus nummularia (bark) and Acacia nilotica (fruit) against Trichostrongylid nematodes of sheep. Journal of Ethnopharmacology, v.123, n.2, p.325-329, 2009.

BAKKALI, F.; AVERBECK, S.; AVERBECK, D.; IDAOMAR, M. Biological effects of essential oils-a review. Food and Chemical Toxicology, v. 46, n. 2, p. 446-475, 2008.

BALLWEBER, R.; BAETEN, L.L.A. Use of macrocyclic lactones in cattle in the USA. Current pharmaceutical biotechnology, v. 13, n. 6, p. 1061-1069, 2012.

BALANDRIN, M. F.; KLOCKE, J. A.; WURTELE, E. S.; BOLLINGER, W. H. Natural plant chemicals: sources of industrial and medicinal materials. Science, v. 228, n. 4704, p. 11541160, 1985.

BANUMATHI, B.; MALAIKOZHUNDAN, B.; VASEEHARAN, B. In vitro acaricidal activity of ethnoveterinary plants and green synthesis of zinc oxide nanoparticles against Rhipicephalus (Boophilus) microp/us. Veterinary Parasitology, v.216, p.93-100, 2016.

BANUMATHI, B.; VASEEHARAN, B.; MALAIKOZHUNDAN, B. et al. Green larvicides against blowflies, Lucilia sericata (Diptera, Calliphoridae): Screening of seven plants used in Indian ethno-veterinary medicine and production of green-coated zinc oxide nanoparticles. Physiological and Molecular Plant Pathology, v.101, p.214-218, 2017.

BELEMLILGA, M.B.; TRAORÉ, A.; OUÉDRAOGO, S. et al. Anthelmintic activity of Saba senegalensis (A. DC.) Pichon (Apocynaceae) extract against adult worms and eggs of 
Haemonchus contortus. Asian Pacific Journal of Tropical Biomedicine, v.6, n.11, p.945949, 2016.

BEYNON, S.A. Potential environmental consequences of administration of anthelmintics to sheep. Veterinary Parasitology, v. 189, n. 1, p. 113-124, 2012.

BRISKIN, D.P.; Medicinal plants and phytomedicines: Linking plant biochemistry and physiology to human health. Plant physiology, v. 124, n. 2, p. 507-514, 2000.

CABARDO, D.E.; PORTUGALIZA, H.P. Anthelmintic activity of Moringa oleifera seed aqueous and ethanolic extracts against Haemonchus contortus eggs and third stage larvae. International Journal of Veterinary Science and Medicine, v.5, n.1, p.30-34, 2017.

CALA, A.C.; CHAGAS, A.C.S.; OLIVEIRA, M.C.S. et al. In vitro anthelmintic effect of Melia azedarach L. and Trichilia claussenii C. against sheep gastrointestinal nematodes. Experimental Parasitology, v.130, n.2, p.98-102, 2012.

CALLANDER, J.T; JAMES, P.J. Insecticidal and repellent effects of tea tree (Melaleuca alternifolia) oil against Lucilia cuprina. Veterinary Parasitology, v.184, n.2, p.271-278, 2012.

CAMPOS, R.N.S.; LIMA, C.B.N.; OLIVEIRA, A.P. et al. Acaricidal properties of vetiver essential oil from Chrysopogon zizanioides (Poaceae) against the tick species Amblyomma cajennense and Rhipicephalus (Boophilus) microplus (Acari: Ixodidae). Veterinary Parasitology, v.212, n.3, p.324-330, 2015.

CAMURÇA-VASCONCELOS, A.L.F.; BEVILAQUA, C.M.L.; MORAIS, S.M. et al. Anthelmintic activity of Croton zehntneri and Lippia sidoides essential oils. Veterinary Parasitology, v.148, n.3, p.288-294, 2007.

CASTILHO, C.V.; FANTATTO, R.R.; GAÍNZA, Y.A. et al. In vitro activity of the essential oil from Hesperozygis myrtoides on Rhipicephalus (Boophilus) microplus and Haemonchus contortus. Revista Brasileira de Farmacognosia, v.27, n.1, p.70-76, 2016.

CASTILLO-MITRE, G.F.; OlMEDO-JUÁREZ, A.; ROJO-RUBIO, R. et al. Caffeoyl and coumaroyl derivatives from Acacia cochliacantha exhibit ovicidal activity against Haemonchus contortus. Journal of Ethnopharmacology, v.204, p.125-131, 2017.

CASTRO, K.N.C.; LIMA, D.F.; VASCONCELOS, L.C. et al. Acaricide activity in vitro of Acmella oleracea against Rhipicephalus microplus. Parasitology Research, v.113, n.10, p.36973701, 2014. 
CAVALCANTE, G.S.; MORAIS, S.M.; ANDRE, W.P. et al. Chemical composition and in vitro activity of Calotropis procera (Ait.) latex on Haemonchus contortus. Veterinary Parasitology, v.226, p.22-25, 2016.

CHAABAN, A.; GOMES, E.N.; SANTOS, V.M. et al. Essential Oils for Myiasis Control: Potentialities for Ecofriendly Insecticides. European Journal of Medicinal Plants, v.21, p.1-25, 2017a.

CHAABAN, A.; SOUZA, A.L.F.; MARTINS, C.E.N. et al. Chemical Composition of the Essential Oil of Tagetes minuta and Its Activity against Cochliomyia macellaria (Diptera: Calliphoridae). European Journal of Medicinal Plants, v.18, n.1, p.1-10, 2017b.

CHAABAN, A.; MARTINS, C.E.N.; BRETANHA, L.C. et al. Insecticide activity of Baccharis dracunculifolia essential oil against Cochliomyia macellaria (Diptera: Calliphoridae). Natural Products Research, p.1-5, 2017c.

CHAABAN, A., SANTOS, V.M.C., GOMES, E., et al. Chemical composition of Piper gaudichaudianum essential oil and its bioactivity against Lucilia cuprina (Diptera: Calliphoridae). Journal of Essential Oil Research, v.30, p.59-166, 2018.

CHAABAN, A.; SANTOS, V. M. C. S., MARTINS, C. E. N., et al. Tissue damage and cytotoxic effects of Tagetes minuta essential oil against Lucilia cuprina. Experimental parasitology, v. 198, p. 46-52, 2019a.

CHAABAN, A., RICHARDI, V.S., CARRER, A., et al. Insecticide activity of Curcuma longa (leaves) essential oil and its major compound $\alpha$ - phellandrene against Lucilia cuprina larvae (Diptera: Calliphoridae): Histological and ultrastructural biomarkers assessment. Pesticides Biochemistry Physiology, v.153, p.17-27, $2019 \mathrm{~b}$.

CHAABAN, A. GOMES, E. N., RICHARDI, V. S. et al. Essential oil from Curcuma longa leaves: Can an overlooked by-product from turmeric industry be effective for myiasis control? Industrial crops and products, v. 132, p. 352-364, 2019c.

CHAGAS, A.C.S.; OLIVEIRA, M.C.S.; GIGLIOTI, R. et al. Efficacy of 11 Brazilian essential oils on lethality of the cattle tick Rhipicephalus (Boophilus) microplus. Ticks and Tick-borne Diseases, v. 7, n.3, p.427-432, 2016.

CHAN-PÉREZ, J.I.; TORRES-ACOSTA, J.F.J.; SANDOVAL-CASTRO, C.A. et al. In vitro susceptibility of ten Haemonchus contortus isolates from different geographical origins towards acetone: water extracts of two tannin rich plants. Veterinary Parasitology, v.217, p.53-60, 2016.

CHAN-PÉREZ, J.I.; TORRES-ACOSTA, J.F.J.; SANDOVAL-CASTRO, C.A. et al. Susceptibility of ten Haemonchus contortus isolates from different geographical origins towards acetone: 
water extracts of polyphenol-rich plants. Part 2: Infective L3 larvae. Veterinary Parasitology, v.240, p.11-16, 2017.

CONCEIÇÃO, R.S.; CARNEIRO, M.M.A.D.A.; REIS, I.M.A. et al. In vitro acaricide activity of Ocotea aciphylla (Nees) Mez. (Lauraceae) extracts and identification of the compounds from the active fractions. Ticks and Tick-borne Diseases, v.8, n.2, p.275-282, 2016.

COSTA-JUNIOR, L.M.; MILLER, R.J.; ALVES, P.B. et al. Acaricidal efficacies of Lippia gracilis essential oil and its phytochemicals against organophosphate-resistant and susceptible strains of Rhipicephalus (Boophilus) microplus. Veterinary Parasitology, v.228, p.60-64, 2016.

COSTA, C.T.C.; BEVILAQUA, C.M.L.; CAMURÇA-VASCONCELOS, A.L.F. et al. In vitro ovicidal and larvicidal activity of Azadirachta indica extracts on Haemonchus contortus. Small Ruminant Research, v.74, n.1, p.284-287, 2008.

CUNHA, S.L.; CARVALHO, M.G.; GUALBERTO, S. et al. Bioatividade do extrato etanólico do caule de Croton linearifolius Mull. Arg. (Euphorbiaceae) sobre Cochliomyia macellaria (Diptera: Calliphoridae). Acta Veterinaria Brasilica, v.4, n.4, 252-258, 2010.

CRUZ, P.B.; BARBOSA, A.F.; ZERINGOTA, V. et al. Acaricidal activity of methanol extract of Acmella oleracea L. (Asteraceae) and spilanthol on Rhipicephalus microplus (Acari: Ixodidae) and Dermacentor nitens (Acari: Ixodidae). Veterinary Parasitology, v.228, p.137-143, 2016.

CRUZ, E.M.O.; COSTA-JUNIOR, L.M.; PINTO, J.A.O. et al. Acaricidal activity of Lippia gracilis essential oil and its major constituents on the tick Rhipicephalus (Boophilus) microplus. Veterinary Parasitology, v.195, n.1, p.198-202, 2013.

CRUZ, A.A.; MOLENTO, M.B. Nanotechnology: meeting the future of Veterinary Parasitology Research. Pesquisa Veterinária Brasileira, v. 35, n. 10, p. 842-843, 2015.

DANTAS, A.C.S.; MACHADO, D.M.R.; ARAUJO, A.C. et al. Acaricidal activity of extracts from the leaves and aerial parts of Neoglaziovia variegata (Bromeliaceae) on the cattle tick Rhipicephalus (Boophilus) microplus. Research in Veterinary Science, v.100, p.165-168, 2015.

DI STASI, L.C.; OLIVEIRA, G.P., CARVALHAES, M.A.; et al. Medicinal plants popularly used in the Brazilian Tropical Atlantic Forest. Fitoterapia, v. 73, n. 1, p. 69-91, 2002.

DOMINGUES, L.F.; GIGLIOTI, R.; FEITOSA, K.A. et al. In vitro and in vivo evaluation of the activity of pineapple (Ananas comosus) on Haemonchus contortus in Santa Inês sheep. Veterinary Parasitology, v.197, n.1, p. 263-270, 2013. 
EGUALE, T.; TADESSE, D.; GIDAY, M. In vitro anthelmintic activity of crude extracts of five medicinal plants against egg-hatching and larval development of Haemonchus contortus. Journal of Ethnopharmacology, v.137, n.1, p.108-113, 2011.

EGUALE, T.; TILAHUN, G.; DEBELLA, A. et al. Haemonchus contortus. in vitro and in vivo anthelmintic activity of aqueous and hydro-alcoholic extracts of Hedera helix. Experimental Parasitology, v.116, n.4, p.340-345, 2007.

ELANDALOUSI, R.B.; AKKARI, H.; B'CHIR, F. et al. Thymus capitatus from Tunisian arid zone: chemical composition and in vitro anthelmintic effects on Haemonchus contortus. Veterinary Parasitology, v.197, n.1, p.374-378, 2013.

ELLSE, L.; WALL, R. The use of essential oils in veterinary ectoparasite control: a review. Medical and veterinary entomology, v. 28, n. 3, p. 233-243, 2014.

FÉBOLI, A.; LAURENTIZ, A.C.; SOARES, S.C. et al.Ovicidal and larvicidal activity of extracts of Opuntia ficus-indica against gastrointestinal nematodes of naturally infected sheep. Veterinary Parasitology, v.226, p.65-68, 2016.

FERNEX, E.; ALONSO-DÍAZ, M.A.; VALLES-DE LA MORA, B. et al. In vitro anthelmintic activity of five tropical legume on the exsheathment and motility of Haemonchus contortus infective larvae. Experimental Parasitology, v.131, n.4, p. 413-418, 2012.

FERRARINI, S.R.; DUARTE, M.O.; ROSA, R.G. et al. Acaricidal activity of limonene, limonene oxide and $\beta$-amino alcohol derivatives on Rhipicephalus (Boophilus) microplus. Veterinary Parasitology, v.157, n.1, p.149-153, 2008.

FERNANDES, F.F.; FREITAS, E.D.P.S. Acaricidal activity of an oleoresinous extract from Copaifera reticulata (Leguminosae: Caesalpinioideae) against larvae of the southern cattle tick, Rhipicephalus (Boophilus) microp/us (Acari: Ixodidae). Veterinary Parasitology, v.147, n.1, p.150-154, 2007.

FERRAZ, B.F.; BALBINO, A.; ZINI, J.M. et al. Acaricidal activity and chemical composition of the essential oil from three Piper species. Parasitology Research, v.107, n.1, p.243-248, 2010.

FERRARINI, S.R.; DUARTE, M.O.; ROSA, R.G. et al. Acaricidal activity of limonene, limonene oxide and $\beta$-amino alcohol derivatives on Rhipicephalus (Boophilus) microplus. Veterinary Parasitology, v.157, n.1, p.149-153, 2008.

FERREIRA, L.E.; BENINCASA, B.I.; FACHIN, A.L. et al. Thymus vulgaris L. essential oil and its main component thymol: Anthelmintic effects against Haemonchus contortus from sheep. Veterinary Parasitology, v.228, p. 70-76, 2016. 
FERREIRA, L.E.; CASTRO, P.M.N.; CHAGAS, A.C.S. et al. In vitro anthelmintic activity of aqueous leaf extract of Annona muricata L. (Annonaceae) against Haemonchus contortus from sheep. Experimental Parasitology, v.134, n.3, p.327-332, 2013.

FORTES, F.S.; MOLENTO, M.B. Anthelmintic resistance in gastrointestinal parasites of small ruminants: Advances and limitations in diagnostic. Pesquisa Veterinária Brasileira, v.33, p.1391-1402, 2013.

FOSTER, J.G.; CASSIDA, K.A.; TURNER, K.E. In vitro analysis of the anthelmintic activity of forage chicory (Cichorium intybus L.) sesquiterpene lactones against a predominantly Haemonchus contortus egg population. Veterinary Parasitology, v.180, n.3, 298-306, 2011.

GAÍNZA, Y.A.; DOMINGUES, L.F.; PEREZ, O.P. et al. Anthelmintic activity in vitro of Citrus sinensis and Melaleuca quinquenervia essential oil from Cuba on Haemonchus contortus. Industrial Crops and Products, v.76, p.647-652, 2015.

GARCIA, M.V.; MATIAS, J.; BARROS, J.C. et al. Chemical identification of Tagetes minuta Linnaeus (Asteraceae) essential oil and its acaricidal effect on ticks. Brazilian Journal of Veterinary Parasitology, v.21, n.4, p.405-411, 2012.

GAZIM, Z.C.; DEMARCHI, I.G.; LONARDONI, M.V.C. et al. Acaricidal activity of the essential oil from Tetradenia riparia (Lamiaceae) on the cattle tick Rhipicephalus (Boophilus) microplus (Acari: Ixodidae). Experimental Parasitology, v.129, n.2, p.175-178, 2011.

GHOSH, S.; SHARMA, A.K.; KUMAR, S. et al. In vitro and in vivo efficacy of Acorus calamus extract against Rhipicephalus (Boophilus) microplus. Parasitology Research, v.108, n.2, p.361-370, 2011.

GIGLIOTI, R.; FORIM, M.R.; OLIVEIRA, H.N.D. et al. In vitro acaricidal activity of neem (Azadirachta indica) seed extracts with known azadirachtin concentrations against Rhipicephalus microp/us. Veterinary Parasitology, v.181, n.2, p. 309-315, 2011.

GOMES, G.A.; MONTEIRO, C.M.O.; SENRA, T.D.O.S. et al. Chemical composition and acaricidal activity of essential oil from Lippia sidoides on larvae of Dermacentor nitens (Acari: Ixodidae) and larvae and engorged females of Rhipicephalus microplus (Acari: Ixodidae). Parasitology Research, v.111, n.6, p. 2423-2430, 2012.

GOVINDARAJAN, M.; RAJESWARY, M., VEERAKUMAR, K.; et al. Novel synthesis of silver nanoparticles using Bauhinia variegata: a recent eco-friendly approach for mosquito control. Parasitology research, v. 115, n. 2, p. 723-733, 2016a.

GOVINDARAJAN, M.; RAJESWARY, M., VEERAKUMAR, K.; et al. Green synthesis and characterization of silver nanoparticles fabricated using Anisomeles indica: mosquitocidal 
potential against malaria, dengue and Japanese encephalitis vectors. Experimental parasitology, v. 161, p. 40-47, 2016b.

GRISI, L., LEITE, R.C., MARTINS, J.R.S., et al. Ressessment of the potential economic impact of cattle parasites in Brazil. Brazilian Journal of Veterinary Parasitology, v.23, n2, p.150156, 2014.

GUNASEKARAN, T.; HAILE, T., NIGUSSE, T.; et al. Nanotechnology: an effective tool for enhancing bioavailability and bioactivity of phytomedicine. Asian Pacific journal of tropical biomedicine, v. 4, p. S1-S7, 2014.

HERNÁNDEZ-VILLEGAS, M.M.; BORGES-ARGÁEZ, R.; RODRIGUEZ-VIVAS, R.I. et al. Ovicidal and larvicidal activity of the crude extracts from Phytolacca icosandra against Haemonchus contortus. Veterinary Parasitology, v.179, n.1, p.100-106, 2011.

HODA, S.M.; FAHMY, M.M.; ATTIA, M.M. et al. The insecticidal activity of two medicinal plants (Commiphora molmol) and (Balanites aegyptiaca) against the blowfly Lucilia sericata (Diptera: Calliphoridae). International Journal of Advanced Research in Biological Sciences, v.3, n.3, p.144-158, 2016.

HOSTE, H.; TORRES-ACOSTA, J. F. J. Non chemical control of helminths in ruminants: adapting solutions for changing worms in a changing world. Veterinary Parasitology, v. 180, n. 1-2, p. 144-154, 2011.

HÜE, T.; CAUQUIL, L.; FOKOU, J.H. et al. Acaricidal activity of five essential oils of Ocimum species on Rhipicephalus (Boophilus) microplus larvae. Parasitology Research, v.114, n.1, p.91-99, 2015.

HUSSAIN, A.; KHAN, M.N.; IQBAL, Z. et al. Anthelmintic activity of Trianthema portulacastrum L. and Musa paradisiaca L. against gastrointestinal nematodes of sheep. Veterinary Parasitology, v.179, n.1, p.92-99, 2011.

IRUM, S.; AHMED, H.; MUKHTAR, M. et al. Anthelmintic activity of Artemisia vestita Wall ex DC. and Artemisia maritima L. against Haemonchus contortus from sheep. Veterinary Parasitology, v.212, n.3, p.451-455, 2015.

JABBAR, A.; ZAMAN, M.A.; IQBAL, Z. et al. Anthelmintic activity of Chenopodium album (L.) and Caesalpinia crista (L.) against trichostrongylid nematodes of sheep. Journal of Ethnopharmacology, v.114, n.1, p.86-91, 2007.

JASSO-DÍAZ, G.; HERNÁNDEZ, G.T.; ZAMILPA, A. et al. In vitro assessment of Argemone mexicana, Taraxacum officinale, Ruta chalepensis and Tagetes filifolia against Haemonchus contortus nematode eggs and infective (L3) larvae. Microbial Pathogenesis, v.109, p.162-168, 2017.

JONSSON, N.N.; PIPER, E.K. Integrated control programs for ticks on cattle. 2007. 
KAMARAJ, C.; RAHUMAN, A.A. Efficacy of anthelmintic properties of medicinal plant extracts against Haemonchus contortus. Research in Veterinary Science, v.91, n.3, p.400404, 2011.

KATIKI, L.M., CHAGAS, A.C.S.; BIZZO, H.R. et al. Anthelmintic activity of Cymbopogon martinii, Cymbopogon schoenanthus and Mentha piperita essential oils evaluated in four different in vitro tests. Veterinary Parasitology, v.183, n.1, p.103-108, 2011.

KHATER, H.F. Prospects of botanical biopesticides in insect pest management. Pharmacologia, v. 3, n. 12, p. 641-656, 2012.

KHATER, H.F.; HANAFY, A.; ABDEL-MAGEED, A.D. et al. Control of the myiasis-producing fly Lucilia sericata with Egyptian essential oils. International Journal of Dermatology, v.50, n.2, p.187-194, 2011.

KHATER, H.F. Bioactivities of some essential oils against the camel nasal botfly, Cephalopina titillator. Parasitology Research, v.113, n.2, p.593-605, 2014.

KHATER, H.F.; RAMADAN, M.Y.; MAGEID, A.D.A. In vitro control of the camel nasal botfly, Cephalopina titillator, with doramectin, lavender, camphor, and onion oils. Parasitology Research, v.112, n.7, p.2503-2510, 2013.

KHATER, H.F.; KHATER, D.F. The insecticidal activity of four medicinal plants against the blowfly Lucilia sericata (Diptera: Calliphoridae). International Journal of Dermatology, v.48, n.5, p. 492-497, 2009.

KOZAN, E.; AKKOL, E.K.; SÜNTAR, I. Potential anthelmintic activity of Pelargonium endlicherianum Fenzl. Journal of Ethnopharmacology, v.187, p.183-186, 2016.

KRIMER-MALEŠEVIĆ, V.; MAĐAREV-POPOVIĆ, S., VAŠTAG, Ž.; et al. Phenolic acids in pumpkin (Cucurbita pepo L.) seeds. In: Nuts and Seeds in Health and Disease Prevention. Academic Press, 2011. p. 925-932.

KUMAR, K.A.; TAYADE, A.B.; KUMAR, R. et al. Chemo-profiling and bioassay of phytoextracts from Ageratum conyzoides for acaricidal properties against Rhipicephalus (Boophilus) microp/us (Acari: Ixodidae) infesting cattle and buffaloes in India. Ticks and Tick-borne Diseases, v.7, n.2, p.342-349, 2016.

KUMARASINGHE, S.P.W.; KARUNAWEERA, N.D.; IHALAMULLA, R.L. et al. Larvicidal effects of mineral turpentine, low aromatic white spirits, aqueous extracts of Cassia alata, and aqueous extracts, ethanolic extracts and essential oil of betel leaf (Piper bet/e) on Chrysomya megacephala. International Journal of Dermatology, v.41, n.12, p.877-880, 2002. 
LAGE, T.C.A.; MONTANARI, R.M.; FERNANDES, S.A. et al. Chemical composition and acaricidal activity of the essential oil of Baccharis dracunculifolia De Candole (1836) and its constituents nerolidol and limonene on larvae and engorged females of Rhipicephalus microplus (Acari: Ixodidae). Experimental Parasitology, v.148, p.24-29, 2015.

LAKSHMI, V.; JOSEPH, S.K., SRIVASTAVA, S., et al. Antifilarial activity in vitro and in vivo of some flavonoids tested against Brugia malayi. Acta tropica, v. 116, n. 2, p. 127-133, 2010. LÁZARO, S.F.; FONSECA, L.D.; MARTINS. E.R. et al. Effect of aqueous extracts of Baccharis trimera on development and hatching of Rhipicephalus microplus (Acaridae) eggs. Veterinary Parasitology, v.194, n.1, p.79-82, 2013.

LIMA, A.S.; SOUSA-FILHO, J.G.N.; PEREIRA, S.G. et al. Acaricide activity of different extracts from Piper tuberculatum fruits against Rhipicephalus microp/us. Parasitology Research, v.113, n.1, p.107-112, 2014.

LISONBEE, L.D.; VILLALBA, J.J.; PROVENZA, F.D. Effects of tannin on selection by sheep of forages containing alkaloids, tannins and saponins. Journal of the Science of Food and Agriculture, v. 89, n. 15, p. 2668-2677, 2009.

LONE, B.A.; CHISHTI, M.Z.; BHAT, F.A. et al. In vitro and in vivo anthelmintic activity of Euphorbia helioscopia L. Veterinary Parasitology, v.189, n.2, p.317-32, 2012.

MADHUMITHA, G.; RAJAKUMAR, G.; ROOPAN, S.M. et al. Acaricidal, insecticidal, and larvicidal efficacy of fruit peel aqueous extract of Annona squamosa and its compounds against blood-feeding parasites. Parasitology Research, v.111, n.5, p.2189-2199, 2012.

MACEDO, I.T.; BEVILAQUA, C.M.; OLIVEIRA, L.M. et al. In vitro activity of Lantana camara, Alpinia zerumbet, Mentha villosa and Tagetes minuta decoctions on Haemonchus contortus eggs and larvae. Veterinary Parasitology, v.190, n.3, p. 504-509, 2012.

MAPHOLI, N.O.; MARUFU, M.C., MAIWASHE, A.; et al. Towards a genomics approach to tick (Acari: Ixodidae) control in cattle: a review. Ticks and tick-borne diseases, v. 5, n. 5, p. 475-483, 2014.

MARIE-MAGDELEINE, C.; HOSTE, H.; MAHIEU, M. et al. In vitro effects of Cucurbita moschata seed extracts on Haemonchus contortus. Veterinary Parasitology, v.161, n.1, p.99-105, 2009.

MARIE-MAGDELEINE, C.; MAHIEU, M.; D'ALEXIS, S. et al. In vitro effects of Tabernaemontana citrifolia extracts on Haemonchus contortus. Research in Veterinary Science, v.89, n.1, p.88-92, 2010a.

MARIE-MAGDELEINE, C.; UDINO, L.; PHILIBERT, L. et al. In vitro effects of Cassava (Manihot esculenta) leaf extracts on four development stages of Haemonchus contortus. Veterinary Parasitology, v.173, n.1, p.85-92, 2010b. 
MARTINEZ-VELAZQUEZ, M.; CASTILLO-HERRERA, G.A.; ROSARIO-CRUZ, R. et al. Acaricidal effect and chemical composition of essential oils extracted from Cuminum cyminum, Pimenta dioica and Ocimum basilicum against the cattle tick Rhipicephalus (Boophilus) microplus (Acari: Ixodidae). Parasitology Research, v.108, n.2, p.481-487, 2011.

MENGISTU, G.; HOSTE, H.; KARONEN, M. et al. The in vitro anthelmintic properties of browse plant species against Haemonchus contortus is determined by the polyphenol content and composition. Veterinary Parasitology, v.237, p.110-116, 2017.

MOLENTO, M.B.; FORTES, F.S.; BUZATTI, A. et al. Partial selective treatment of Rhipicephalus microplus and breed resistance variation in beef cows in Rio Grande do Sul, Brazil. Veterinary Parasitology, v.192, p.234-239, 2013.

MOLENTO, M.B.; FORTES, F.; PONDELEK, D. et al. Challenges of nematode control in ruminants: focus on Latin America. Veterinary Parasitology, v.180, p.126-132, 2011.

MONTEIRO, M.V.B.; BEVILAQUA, C.M.; MORAIS, S.M. et al. Anthelmintic activity of Jatropha curcas L. seeds on Haemonchus contortus. Veterinary Parasitology, v.182, n.2, p.259-263, 2011.

MONTEIRO, I.N.; MONTEIRO, O.S.; COSTA-JUNIOR, L.M. et al. Chemical composition and acaricide activity of an essential oil from a rare chemotype of Cinnamomum verum Presl on Rhipicephalus microplus (Acari: Ixodidae). Veterinary Parasitology, v.238, p.54-57, 2017.

MORAIS-COSTA, F.; BASTOS, G.A.; SOARES, A.C.M. et al. In vitro and in vivo action of Piptadenia viridiflora (Kunth) Benth against Haemonchus contortus in sheep. Veterinary Parasitology, v.223, p. 43-49, 2016.

MORENO-GONZALO, J.; MANOLARAKI, F.; FRUTOS, P. et al. In vitro effect of heather (Ericaceae) extracts on different development stages of Teladorsagia circumcincta and Haemonchus contortus. Veterinary Parasitology, v.197, n.1, p.235-243, 2013.

MOYA-BORJA GE. Erradicação ou manejo integrado das miíases neotropicais das Américas. Pesquisa Veterinária Brasileira, v.23, n.32, p.131-138, 2003.

NAUMANN, H. D.; ARMSTRONG, S. A.; LAMBERT, B. D. et al. Effect of molecular weight and concentration of legume condensed tannins on in vitro larval migration inhibition of Haemonchus contortus. Veterinary parasitology, v. 199, n. 1-2, p. 93- 98, 2014.

OLIVEIRA, L.M.B.; BEVILAQUA, C.M.L.; COSTA, C.T.C. et al. Anthelmintic activity of Cocos nucifera L. against sheep gastrointestinal nematodes. Veterinary Parasitology, v.159, n.1, p.55-59, 2009. 
OLIVEIRA, A.F.; JUNIOR, L.M.C.; LIMA, A.S. et al. Anthelmintic activity of plant extracts from Brazilian savanna. Veterinary Parasitology, v.236, p.121-127, 2017.

PAPAVERO, N., COURI, M.C. Essays on thehistory of Brazilian dipterology. I. The first notices about Brazilian Diptera (16 th century). Revista Brasileira de Entomologia, v.56, n.1, p.:1-6, 2012a.

PAPAVERO, N., COURI, M.C. Essays on the history of Brazilian dipterology. III. Three remarkable notices from the 18 th century, mainly related to myiasis-producing flies (Cochliomyia and Dermatobia). Revista Brasileira de Entomologia, v.56, n.4, p.393-398, 2012b.

PARVEEN, S.; GODARA, R.; KATOCH, R. et al. In vitro evaluation of ethanolic extracts of Ageratum conyzoides and Artemisia absinthium against cattle tick, Rhipicephalus microplus. The Scientific World Journal, p.1-6, 2014.

PAVELA, R. Essential oils for the development of eco-friendly mosquito larvicides: a review. Industrial Crops and Products, v.76, p.174-187, 2015.

PAVELA, R.; BENELLI, G. Essential oils as ecofriendly biopesticides? Challenges and constraints. Trends in plant science, v. 21, n. 12, p. 1000-1007, 2016.

PAZINATO, R.; VOLPATO, A.; BALDISSERA, M.D. et al. In vitro effect of seven essential oils on the reproduction of the cattle tick Rhipicephalus microp/us. Journal of Advanced Research, v.7, n.6, p.1029-1034, 2016.

PINTO, Z.T.; FERNANDEZ-SANCHEZ, F.E.; SANTOS, A.R. et al. Effect of Cymbopogon citrates (Poaceae) oil and citral on post-embryonic time of blowflies. Journal of Entomology and Nematology, v.7, n.6, 54-64, 2015.

PREET, S.; TOMAR, R.S. Anthelmintic effect of biofabricated silver nanoparticles using Ziziphus jujuba leaf extract on nutritional status of Haemonchus contortus. Small Ruminant Research, v.154, p.45-51, 2017.

QI, H.; WANG, W.X.; DAl, J.L. et al. In vitro anthelmintic activity of Zanthoxylum simulans essential oil against Haemonchus contortus. Veterinary Parasitology, v.211, n.3, 223-227, 2015.

RAJAKUMAR, G.; RAHUMAN, A.A. Acaricidal activity of aqueous extract and synthesized silver nanoparticles from Manilkara zapota against Rhipicephalus (Boophilus) microplus. Research in Veterinary Science, v.93, n.1, p.303-309, 2012.

REGNAULT-ROGER, C.; VINCENT, C.; ARNASON, J.T. Essential oils in insect control: lowrisk products in a high-stakes world. Annual Review of Entomology, v. 57, p. 405-424, 2012. 
RIBEIRO, V.L.S.; TOIGO, E.; BORDIGNON, S.A. et al. Acaricidal properties of extracts from the aerial parts of Hypericum polyanthemum on the cattle tick Boophilus microplus. Veterinary Parasitology, v.147, n.1, p.199-203, 2007.

RIBEIRO, V.L.S.; AVANCINI, C.; GONÇALVES, K. et al. Acaricidal activity of Calea serrata (Asteraceae) on Boophilus microplus and Rhipicephalus sanguineus. Veterinary Parasitology, v.151, n.2, p.351-354, 2008.

RIBEIRO, V.L.S.; SANTOS, J.C.; BORDIGNON, S.A. et al. Acaricidal properties of the essential oil from Hesperozygis ringens (Lamiaceae) on the cattle tick Riphicephalus (Boophilus) microp/us. Bioresource Technology, v.101, n.7, p.2506-2509, 2010.

RIBEIRO, V.L.S.; SANTOS, J.C.; MARTINS, J.R. et al. Acaricidal properties of the essential oil and precocene II obtained from Calea serrata (Asteraceae) on the cattle tick Rhipicephalus (Boophilus) microplus (Acari: Ixodidae). Veterinary Parasitology, v.179, n.1, p.195-198, 2011.

RIBEIRO, W.L.C.; CAMURÇA-VASCONCELOS, A.L.F.; MACEDO, I.T.F. et al. In vitro effects of Eucalyptus staigeriana nanoemulsion on Haemonchus contortus and toxicity in rodents. Veterinary Parasitology, v.212, n.3, p.444-447, 2015.

RIBEIRO, J.C.; RIBEIRO, W.L.C.; CAMURÇA-VASCONCELOS, A.L.F. et al. Efficacy of free and nanoencapsulated Eucalyptus citriodora essential oils on sheep gastrointestinal nematodes and toxicity for mice. Veterinary Parasitology, v.204, n.3, p.243-248, 2014.

RIGHI, A.A.; MOTTA, L.B.; KLAFKE, G.M. et al. Chemical composition and efficacy of dichloromethane extract of Croton sphaerogynus Baill (Euphorbiaceae) against the cattle tick Rhipicephalus microplus (Acari: Ixodidae). Veterinary Parasitology, v.192, n.1, 292295, 2013.

ROSADO-AGUILAR, J. A.; AGUILAR-CABALLERO, A., RODRIGUEZ-VIVAS, R. I.; et al. Acaricidal activity of extracts from Petiveria alliacea (Phytolaccaceae) against the cattle tick, Rhipicephalus (Boophilus) microplus (Acari: ixodidae). Veterinary Parasitology, v. 168, n. 3-4, p. 299-303, 2010.

SANDEMAN, R.M., LEVOT, G.W., HEATH, A.C.G. et al. Control of the sheep blowfly in Australia and New Zealand - are we there yet? International Journal for Parasitology, v.44, p.879-891, 2014.

SANTHOSHKUMAR, T.; RAHUMAN, A.A.; BAGAVAN, A. et al. Evaluation of stem aqueous extract and synthesized silver nanoparticles using Cissus quadrangularis against Hippobosca maculata and Rhipicephalus (Boophilus) microplus. Experimental Parasitology, v.132, n.2, p.156-165, 2012. 
SANTOS, C.; CAMPESTRINI, L.H.; VIEIRA, D.L. et al. Chemical Characterization of Opuntia ficus-indica (L.) Mill. Hydroalcoholic Extract and Its Efficiency against Gastrointestinal Nematodes of Sheep. Veterinary Sciences, v.5, p. 20-33, 2018.

SEDDIEK, S.A.; ALI, M.M., KHATER., H.F.; et al. Anthelmintic activity of the white wormwood, Artemisia herba-alba against Heterakis gallinarum infecting turkey poults. Journal of Medicinal Plants \& Research, v.5, n.16, p.3946-3957, 2011.

SENRA, T.D.O.S.; ZERINGÓTA, V.; MONTEIRO, C.M.O. et al. Assessment of the acaricidal activity of carvacrol, (E)-cinnamaldehyde, trans-anethole, and linalool on larvae of Rhipicephalus microplus and Dermacentor nitens (Acari: Ixodidae). Parasitology Research, v.112, n.4, p.1461-1466, 2013.

SHALABY, H.A.; EL KHATEEB, R.M.; EL NAMAKY, A.H. et al. Larvicidal activity of camphor and lavender oils against sheep blowfly, Lucilia sericata (Diptera: Calliphoridae). Journal of Parasitic Diseases, v.40, n.4, p.1475-1482, 2016.

SHYMA, K.P.; GUPTA, J.P.; GHOSH, S. et al. Acaricidal effect of herbal extracts against cattle tick Rhipicephalus (Boophilus) microplus using in vitro studies. Parasitology Research, v.113, n.5, p.1919-1926, 2014.

SILVA, W.C.; MARTINS, J.R.S.; CESIO, M.V. et al. Acaricidal activity of Palicourea marcgravii, a species from the Amazon forest, on cattle tick Rhipicephalus (Boophilus) microplus. Veterinary Parasitology, v.179, n.1, p.189-194, 2011.

SILVA, W.C.; MARTINS, J.R.S.; SOUZA, H.E.M. et al Toxicity of Piper aduncum L. (Piperales: Piperaceae) from the Amazon forest for the cattle tick Rhipicephalus (Boophilus) microplus (Acari: Ixodidae). Veterinary Parasitology, v.164, n.2, p.267-274, 2009.

SILVEIRA, R.X.; CHAGAS, A.C.S.; BOTURA, M.B. et al. Action of sisal (Agave sisalana, Perrine) extract in the in vitro development of sheep and goat gastrointestinal nematodes. Experimental Parasitology, v.131, n.2, p.162-168, 2012.

SINGH, A.; KAUR, J. The bioefficacy of crude extracts of Azadirachta indica (Meliaceae) on the survival and development of myiasis-causing larvae of Chrysomya bezziana (Diptera: Calliphoridae). Tropical Animal Health and Production, v.48, n.1, p.117-124, 2016.

SOLDERA-SILVA, A.; SEYFRIED, M.; CAMPESTRINI, L. et al. Assessment of anthelmintic activity and bio-guided chemical analysis of Persea americana seed extracts. Veterinary Parasitology, v.251, p.34-43, 2018.

SPRENGER, L.K.; BUZATTI, A.; CAMPESTRINI, L.H; et. al. Atividade ovicida e larvicida do extrato hidroalcoólico de Artemisia annua sobre parasitas gastrintestinais de bovinos. Arquivo Brasileiro de Medicina Veterinária e Zootecnia, v. 67, p. 25-31, 2015. 
STRATAKOS, A.; KOIDIS, A. Methods for extracting essential oils. In: Essential Oils in Food Preservation, Flavor and Safety. Academic Press, 2016. p. 31-38.

TARIQ, K.A.; CHISHTI, M.Z.; AHMAD, F. et al. Anthelmintic activity of extracts of Artemisia absinthium against ovine nematodes. Veterinary Parasitology, v.160, n.1, p.83-88, 2009.

TADESSE, D.; EGUALE, T.; GIDAY, M. et al. Ovicidal and larvicidal activity of crude extracts of Maesa lanceolata and Plectranthus punctatus against Haemonchus contortus. Journal of Ethnopharmacology, v.122, n.2, p.240-244, 2009.

VALENTE, P.P.; AMORIM, J.M.; CASTILHO, R.O. et al. In vitro acaricidal efficacy of plant extracts from Brazilian flora and isolated substances against Rhipicephalus microplus (Acari: Ixodidae). Parasitology Research, v.113, n.1, p.417-423, 2014.

VALLAD, G.; GOODMAN, R.M. Systemic acquired resistance and induced systemic resistance in conventional agriculture. Crop Science, v. 44, n. 6, p. 1920-1934, 2004.

VERMA, N.; SHUKLA, S. Impact of various factors responsible for fluctuation in plant secondary metabolites. Journal of Applied Research on Medicinal and Aromatic Plants, v. 2, n. 4, p. 105-113, 2015.

WALL, R. Ovine cutaneous myiasis: effects on production and control. Veterinary Parasitology, v.189, p.44-51, 2012.

WARDHANA, A.H.; DIANA, N. Biolarvacidal activity of methanol extract of Kipahit leaves (Tithonia diversifolia) against larvae of Chrysomya bezziana fly. Indonesian Journal of Animal and Veterinary Sciences, v.19, n.1, p.43-51, 2014.

WEBSTER, A.; RECK, J., SANTI, L.; et al. Integrated control of an acaricide-resistant strain of the cattle tick Rhipicephalus microplus by applying Metarhizium anisopliae associated with cypermethrin and chlorpyriphos under field conditions. Veterinary parasitology, v. 207, n. 3-4, p. 302-308, 2015.

WELLINGTON, K.W.; LEBOHO, T.; SAKONG, B.M. et al. Further studies on South African plants: Acaricidal activity of organic plant extracts against Rhipicephalus (Boophilus) microplus (Acari: Ixodidae). Veterinary Parasitology, v.234, p.10-12, 2017.

WHO. General guidelines for methodologies on research and evaluation of traditional medicine. Document WHO/EDM/TRM/2000.1. Geneva; p. 184, 2000.

WHO. National policy on traditional medicine and regulation of herbal medicines. Report of a WHO global survey. May, 2005. Geneva; p. 156, 2005.

WHO. WHO guidelines for assessing quality of herbal medicines with reference to contaminants and residues. Geneva, p.118, 2007. 
ZHU, L.; DAÍ, J.; YANG, L. et al. Anthelmintic activity of Arisaema franchetianum and Arisaema lobatum essential oils against Haemonchus contortus. Journal of Ethnopharmacology, v.148, n.1, p.311-316, $2013 a$.

ZHU, L.; DAl, J.; YANG, L. et al. In vitro ovicidal and larvicidal activity of the essential oil of Artemisia lancea against Haemonchus contortus (Strongylida). Veterinary Parasitology, v.195, n.1, p.112-117, 2013b. 